\title{
ABUNDANT HIGHER PLANT-DERIVED \\ BIOMARKERS IN LIGHT OILS AND \\ CONDENSATES FROM THE COAL- bearing Xihu SAg, EAST China Sea SHELF BASIN
}

\author{
XiOng ChenG ${ }^{1}$, DujIe Hou ${ }^{1}$, Zhe ZHAO ${ }^{1}$, YuHAN \\ JIANG $^{1}$ \\ ${ }^{1}$ School of Energy Resources, China University of \\ Geosciences, Beijing, China, xcheng2015@cugb.edu.cn; \\ hdj@cugb.edu.cn; 2587628033@qq.com; \\ 693947627@qq.com
}

The biomarker assemblages have been studied in detail from a suite of recently discovered light oils and condensates from the Paleogene coal-bearing Xihu Sag of East China Sea Shelf Basin, using gas chromatography-mass spectrometry in order to understand their thermal maturity, depositional environment, and source materials. The $n$-alkane with slight odd over even preference over $n$ - $\mathrm{C}_{25}$, relatively high $\mathrm{Pr} / n-\mathrm{C}_{17}$ ratios, and isomerisation ratios of $\mathrm{C}_{29}$ steranes and $\mathrm{C}_{31}$ homohopanes, suggest that the liquids have a relatively low maturity in the early to mid-oil generation window. The distribution of isoprenoids relative to $n$-alkanes, high $\mathrm{Pr} / \mathrm{Ph}$ ratios (5.1-10.7), almost absence of gammacerane and $\mathrm{C}_{33+}$ homohopanes, and low DBT/P ratios indicate that the source rocks of the liquids were deposited in an oxic and sulphatepoor fluvio-deltaic environment within an unstratified water column. Abnormally abundant gymnosperm-derived diterpanes, including labdane, 19-norisopimarane, fichtelite, rimuane, pimarane, isopimarane, 17-nortetracyclic diterpene, phyllocladanes and abietane, were detected. In addition, three 19-norisopimarane isomers, $13 \beta(\mathrm{H})$-atisane, and 20normethylatisane were tentatively identified in the studied samples. Abundant middle to high-molecular-weight $n$ alkanes with slight odd over even preference, isoprenoids distribution, a dominance of $\mathrm{C}_{29}$ steranes without $\mathrm{C}_{27}$ homologues, the presence of $4 \beta(\mathrm{H})$-eudesmane and oleanane, and abundant diterpanes ascertain that the liquids were derived predominantly from higher plant source materials. Among the gymnosperms, Cupressaceae (especially the former Taxodiaceae) and Pinaceae were the major source of the diterpanes, and had significant contribution to the liquid hydrocarbons. The contribution by angiosperms versus gymnosperms could be underestimated if only based on the low abundance of oleanane relative to diterpanes, due to differential preservation and alteration of the di- and triterpenoids precursors during diagenesis and the occurrence of nonspecific precursors in higher land plants. 